Valóságos könyvtár - könyvtári valóság. Könyvtár- és információtudományi tanulmányok 2018. Szerk. Kiszl Péter, Csík Tibor.

Budapest, ELTE BTK Könyvtár- és Információtudományi Intézet. 2018. 321-328.

\title{
AKIKET A HITELKÁRTYA ÉS A KÖNYVTÁR ÖSSZEKÖT: A KÖNYVTÁR MINT A CRM ESZKÖZE A HYUNDAI CARD GYAKORLATÁBAN
}

\author{
JUHÁSZ ÉVA \\ Magyar Képzőművészeti Egyetem Könyvtár, Levéltár és Művészeti Gyűjtemény, \\ könyvtáros
}

\section{TARTALMI ÖSSZEFOGLALÓ}

A nemzetközi profitorientált vállalatok CRM politikája egyre erőteljesebben összpontosít a társadalmi felelősségvállalásra. A dél-koreai Hyundai Card a közösségépítésre és a kultúra támogatására helyezi a hangsúlyt. Célja a bizalom kiépítése, amely hosszú távon húséget és elégedettséget, tehát tartós bevételt biztosít a vállalat számára. Ennek érdekében alapították a négy Hyundai Card könyvtárat, amelyek nem nyilvánosak, de - éppen az ügyfélszerzés céljából - látogatásuk feltételei kedvezőek. A könyvtárak teljes jogú tagjai a vállalat ügyfelei, akik a kreditkártyájukat használják olvasó- és kölcsönzőjegyként. A példákból leszűrhető, hogy a vállalat igyekszik megszólítani azt a fogyasztói kört, akiket a hitelkártya és a könyvtár összeköt. A gyakorlat annyira új és egyedi, hogy még nem vizsgálták ezen innovatív CRM lehetséges faktorait. Jelen tanulmány az ország értékteremtő hagyományait, a kommersz filmek kultúraközvetítő szerepét, valamint a vállalat dinamikus szervezeti képességeit vizsgája.

\section{Bevezetés}

A termelő és a szolgáltató szektorban egyre nagyobb hangsúlyt kap az ügyfél jövedelmezősége és megtarthatósága. A megváltozott piaci igények figyelembevételével már nem közvetlenül terméket vagy szolgáltatást, hanem élményt, stílust, életérzést, törődést vagy társadalmi felelősséget kínálnak. ${ }^{1}$ Ezt a piaci stratégiát segíti az ügyfélkapcsolati menedzsment (Costumer Relationship Management, CRM), amely „olyan össquállalati ügyfélkëöpontú stratégia, mely a vállalati folyamatokat a乏 ügyféligények minél eredményesebb kišolgálása érdekében integrálja egy, a legmodernebb technológiát képviseló informatikai megoldásba, melynek alapjául egy minden ügyféladatot tartalmazó adattárbáz szolgál. Az informatikai támogatás és az egységes adatbázis révén lehetövé válik az ügyfélfolyamatok automatizálása és az ügyféladatok feldolgozása a nyereség maximalizálása érdekében. Az ügyfélkapcsolatok kezelésének kiemelten fontos eleme az emberi tényezọ." "2 
JUHÁsz ÉVA

\section{A Hyundai Card könyvtárai}

A dél-koreai Hyundai Motor Groupot 1947-ben alapították. Központja Szöulban múködik. Leányvállalata, a Hyundai Card banki szolgáltatást nyújt, CRM stratégiájában pedig a közösségépítésre és a kultúra támogatására helyezi a hangsúlyt. Célja, hogy mély bizalmat építsen ki a fogyasztóban, amely hosszú távon hűséget és elégedettséget, tehát tartós bevételt biztosít. Ennek nyomán épültek fel a Hyundai Card könyvtárak, amelyeknek teljes jogú tagjai a cég ügyfelei. Olvasójegyként a saját bankkártyájukat használják. A könyvtárak látogatási feltételei ugyanakkor a külső felhasználók számára is kedvezőek, ennek nem titkolt célja: új ügyfelek szerzése. A banki szolgáltatás alapvető eleme a fenti definícióban említett adattárház, amely a fogyasztói szokások követését biztosítja, és megkönnyíti a piaci szegmentációt. Ezáltal lehetővé válik a lehető legszélesebb körű fogyasztói kör megszólítása, ugyanakkor definiálhatók a banki szolgáltatásokat igénybe vevő csoportok is: akiket a hitelkártya és a könyvtár összeköt.

A Hyundai Card Design Libraryt 2013-ban nyitották meg Szöul hajdani nemesi és tudós negyedében. A 11000 kötetet nemzetközi szakértők segítségével válogatták össze. Az épületben a könyvgyüjteményen kívül helyet kapott egy kávézó, egy kiállítóterem, valamint egy társalgó. A legfelső emeleten található tanulószoba a hajdani koronahercegek korát idézi, ezzel is inspirálva az egyetemi vizsgára való felkészülést. A vállalat a környezet kialakításával azt kívánja éreztetni: a „Hyundai Kártya: gazdagabb életstílus”.

A Hyundai Card Travel Library 2014-ben nyílt Szöul déli részén fekvő, gazdag, forgalmas üzleti negyedében, azzal a céllal, hogy ügyfeleket csábítson el a rivális cégektől, illetve „hogy a látogatók a napi rutinból kiszakadva pihenjenek, és a könyvek segitségével tervezzék. utazásaikat'. A 14700 kötetet három témakör szerint csoportosították: múvészet-építészet, kaland és úti fotók. Megtalálható a teljes National Geographic a történelmi térképekkel, valamint az ahhoz kapcsolódó témakörökkel foglalkozó, angol nyelvú tudományos folyóirat, az Imago Mundi is. ${ }^{4}$

A Hyundai Card Music Libraryt 2015-ben adták át Szöul nemzetközi kulturális és szórakoztató övezetében. A kétszintes könyvtár és zenei gyüjtemény mintegy 10000 kölcsönözhető hanglemezt tartalmaz. Megvan a teljes Rolling Stones magazin. Az alagsorban koncertezésre alkalmas underground színpad található, emellett gyakorlásra és demófelvételek készítésére alkalmas stúdiók is rendelkezésre állnak. A vállalat szóvivője szerint „a kártyatulajdonosainknak nyújtott élménnyel saját márkaértékünket növeljük."

A Hyundai Card Cooking Library 2017-ben nyílt meg Szöul hipszter negyedében. A bank képviselőinek szavaival élve azért, hogy ,érzelmi kapcsolatot épitsünk ki az ügyfeleink.kel’. A könyvtárban közel 11000 konyhamúvészettel kapcsolatos elméleti és gyakorlati kötet található, továbbá az otthonosság jegyében egy gyakorló konyhát is építettek, ahova séfeket és gasztrobloggereket is meghívnak. A közösségi élményszerzést a saját étterem is elősegíti, szezonális különlegességeket kínálva. ${ }^{5}$ 
AKIKET A HITELKÁRTYA ÉS A KÖNYVTÁR ÖSSZEKÖT: A KÖNYVTÁR MINT A CRM...

\section{Miért a könyvtárak? A könyvtárak CRM eszközként való használatának lehetséges indokai}

„Nem egészen világos, hogy Dél-Korea legnagyobb kreditkártya kibocsátója miért kötelezi el magát a kreativ elvek mentén, de a könyvárak épitése messze túlmutat a pén zügyi tevékenységen." ${ }^{\circ}$ Az idézet a Times Inc. kiadó rangos nemzetközi építészeti és iparművészeti folyóiratának, a Wallpaper online változatának egyik írásából származik. A gyakorlat annyira új és egyedi, hogy nem születtek még nemzetközi tudományos publikációk, amelyek mélységeiben feltárták volna ennek hátterét, annál is inkább, mert a kísérlet kimenetele még ismeretlen. Versenyszférában szerzett tapasztalattal rendelkező könyvtárosként arra teszek kísérletet, hogy a Hyundai innovatív CRM stratégiájának lehetséges okait, tényezőit legalább részben megvilágítsam. A következőkben e tényezők bemutatására kerül sor.

\section{I. Értékteremtö hagyományok}

\section{I.1. Kulturális értékeke, történelmi örökség: a megörzés}

E hagyományt a Kyujanggak Királyi Könyvtár fémjelzi, amelyet Dzsong Dzso király 1776ban, trónra lépésének évében alapított. Eredeti célja az volt, hogy megőrizze a Csószon dinasztia királyai által jegyzett műveket, de később kibővült egy tanácsadói szervezeti funkcióval. A hivatalnokok és tanácsadók itt készülhettek fel a hazai és külföldi gazdasági és politikai ügyekben, amelyeket aztán a királlyal való tanácskozás során vitattak meg. A könyvtár később saját kiadóval, valamint az irodai felszerelések hivatalával bővült. Jelenleg a Seoul National University Kyujanggak Institute for Korean Studies könyvtáraként működik. ${ }^{7}$ Gyűjteményében megtalálhatók az UNESCO Szellemi Kulturális Örökség részét képező Csószon dinasztia évkönyvei, valamint a királyi protokoll könyve, az Uigwe. Az évkönyvek az alapítástól, 1392-tôl 1863-ig jegyzik a királyi udvar történéseit. Az 1893 kötetből álló dokumentumsorozat évekre, hónapokra és napokra lebontva szolgáltat történelmileg hiteles adatokat a korabeli politikai, gazdasági, hadügyi, társadalmi, kulturális és tudományos eseményekről. A pártatlanságot az is biztosította, hogy a korabeli történetírók függetlenek voltak a királytól. ${ }^{8}$ Az eredeti példányokat gondosan őrzik. Az unikális képi forrásként elismert Uigwe a királyi udvar szertartásainak, eseményeinek pontos, gazdagon illusztrált forgatókönyveit tartalmazza. ${ }^{9}$ A két dokumentum digitalizált változata hangul és kínai változatban, adatbázisban feldolgozva a nagyközönség számára is hozzáférhető, és oktatási, valamint személyes célokra korlátozottan felhasználható. ${ }^{10}$

\section{I.2. A társadalmi felelósségvállalás hagyománya}

„A közemberek alkotják az ország alapját. Csakis akekor, ha az alap erös, csakis ak.kor lehet egy ország stabil és virágæó." 11 - vallotta Nagy Szedzsong (1397-1450), a Csószon dinasztia negyedik, egyben legnagyobb hatású uralkodója, aki hitte, hogy népe alakíthatja a saját életét, és képes a társadalmi, kulturális, valamint spirituális felemelkedésre. Hitvallása szerint a király kötelessége, hogy ebben segítségére legyen. Legnagyobb öröksége az 1443-ban befejezett koreai abc, a hangul (Nagy Írás; Korea Írása): „A tanulatlan emberek kö̌ött is 


\section{JUHÁsz ÉVA}

vannak sokan, akik szeretnék, de nem tudják írásban kifejezni érzéseiket. Ez nagyon elszomorit, tehát megalkottam 28 betüt. Használja könnyedén bárki a mindennapok során."12 Az együttérzés ábécéjének is nevezett hangul anatómiai kutatásokon, nyelvészeti tanulmányokon, filozófiai megközelítésen alapul. ${ }^{13}$ Logikus rendszerének köszönhető, hogy a számítógép korszakában rendkívül megkönnyíti a szövegfelismerést, segíti a programozást, valamint az internetes applikációk létrehozását. ${ }^{14}$ Jelentőségét mutatja, hogy az Olvasás Világnapján, szeptember 8-án adják át az írástudás terjesztését elismerő, 1989-ben alapított nemzetközi díjat, melynek neve: UNESCO King Sejong Literacy Prize. ${ }^{15}$

\section{I.3. Azi innováció hagyománya}

A XV. század első felében világszerte jegyzett 62 tudományos újítás közül 29 Koreában, Nagy Szedzsong uralkodása alatt született. ${ }^{16}$ A korszak legnagyobb tudósa, újítója és feltalálója Jang Yeol Sil (1380?-1442?). Találmányai között szerepel a nap- és a vízóra, amelyek segítségével szabályozhatóvá vált a mezőgazdasági munka, a kereskedelem, a hajózás és a városgazdálkodás. ${ }^{17}$

\section{I.4. A tisztességes keereskedelem hagyománya}

A vevő valódi igényét figyelembe vevő, tisztességes kereskedelem ikonikus figurája Kim Man Deok (1739-1812), az első női vezérigazgató. A Jeju szigetén élő filantróp üzletaszszony Dzsong Dzso király uralkodása alatt tevékenykedett. Az 1794-es éhínség idején felszámolta értékeit, hogy segítsen a bajbajutottakon: rendszeres ételosztással több ezer embert mentett meg az éhhaláltól. Érvei között szerepelt: ahhoz, hogy a boltot újra kinyissa, a vevőknek életben kell maradniuk. Tettéért a király magas hivatali tisztséget bízott rá. ${ }^{18}$

\section{A kommersz filmek kultúraközvetitó szerepe}

A Koreai Köztársaság Kulturális, Sport és Turizmus Minisztériuma nagy gondot fordít arra, hogy kulturális örökségét belföldön és külföldön népszerűsítse. ${ }^{19}$ Az intézmény, amely egyben a Nemzeti Színház, a Nemzeti Múzeum, valamint az 1945-ben alapított Koreai Nemzeti Könyvtár fenntartója is, ${ }^{20}$ kihasználja a kommersz filmekben rejlô lehetőségeket, amelyeknek jelentőségére az 1993-as Spielberg-rendezte Jurassic Park sikere ébresztette rá a koreai szakembereket: a film bevétele akkora volt, mintha Korea egy év alatt 1,5 millió autót exportált volna. ${ }^{21}$ Az elkészült koreai filmek jelentős nemzetközi sikereket értek el, amelyhez hozzájárul a már ismertetett Uigwe, a királyi évkönyvek, valamint a fennmaradt naplók és a korabeli szakkönyvek, amelyek egyedülálló forrásként szolgálnak a történelmi filmsorozatok forgatókönyvírói, látványtervezői és operatôrei számára. További sikerfaktor a jó megjelenésű szereplőgárda, a minden részleteiben kidolgozott színészi munka, valamint a múvelt és igényes felvevőpiac. ${ }^{22}$ Megfigyelhető, hogy számos alkotásban szerepel a könyvtár, amelyet néhány film rövid bemutatásával illusztrálok.

Nagy Szedzsong életét $A$ mély gyökerü fa ${ }^{23}$ és a Nagy Szedzsong király ${ }^{24}$ címú filmek idézik fel, amely történetekben Jang Yeol Sil is szerepel. Korabeli ábrázolások alapján 
bemutatják a herceg tanulószobáját és könyvtárát (vö. Hyundai Design Library). A könyvtár mint helyszín, valamint a karakterábrázolás eszköze további filmekben is megjelenik. A magyar tévécsatornákon is sugárzott $A$ korona hercege c. sorozat Dzsong Dzso király (1752-1800) uralkodását, életét tárgyalja, amelyben külön történeti szálat kap a Kyujanggak (a királyi könyvtár) alapítása. Ebben a korban játszódik a Sungkyunkwan botrány is, ${ }^{25}$ amely az 1398-ban alapított, nagy presztízsű Sungkyunkwan Egyetem életébe enged betekintést. A filmbeli könyvtár titkos tárgyalások, plátói romantikus jelenetek helyszíne. Az In-Hyun királyné embere ${ }^{26}$ az időutazó műfajba tartozik. A Szuk Dæsong király idejéből (1700-as évek eleje) származó művelt főhős, a nemes ifjú, Kim Boong-Do a könyvtárban járva hirtelen 2012-ben találja magát, ahol találkozik a jelenkori filmcsillaggal, Choi Hee-Jinnel, és rendszeresen látogatják a modern Sungkyunkwan Egyetem könyvtárát. Ezt a múfajt a készítők is kedvelik, mert a korabeli cselekménnyel párhuzamosan futó mai jelenetek kiváló reklámfelületként szolgálnak, az ázsiai nézők pedig egyszerre tisztelhetik a múlt tradícióit és üdvözölhetik a globalizációt. ${ }^{27} \mathrm{~A}$ könyvtár a jelenkort ábrázoló filmekben is megjelenik. A Sžífájdalom Könyvtár ${ }^{28}$ cselekménye során kiderül, hogy a szupernet és az okostelefonos applikációk ellenére a könyvtár fontos a felhasználók számára: közösséget biztosít és tanulásra ösztönöz. A könyvtárosok pedig igyekeznek a kedvükben járni, például egy füthető szőnyeggel. A Man to man című produkcióban a külföldi helyszínek között Budapest és az Egyetemi Könyvtár is feltűnik. ${ }^{29}$

A legtöbb film ingyenesen, feliratozva, jogtisztán hozzáférhető. A koreai filmek kultusza manapság számos külföldi turistát vonz az országba, akik felkeresik a filmekben látható emblematikus helyszíneket: a múzeumok, könyvtárak mellett plasztikai sebészeti központokat, áruházakat, kávézókat, éttermeket, és megvásárolják a filmben látott termékeket. A filmipar tehát a forprofit szektor többi szereplöire is kedvező hatást gyakorol. ${ }^{30}$ A gyártók és szolgáltatók forgalma emelkedik, nyereségük nő, a befolyt adóból pedig a kulturális intézmények - köztük a könyvtárak - is részesülnek.

\section{A Hyundai Card dinamikus sžervezeti képességei}

A Hyundai szó jelentése „,modernitás”, amely illeszkedik a cég jelenlegi szlogenjébe: „Új gondolkodás. Új lehetöségek”. Logója a „H” egyrészt a vállalat nevének rövidítése, másrészt stilizált kép: a vállalat képviselóje és az elégedett ügyfél kezet fog. A jobbra dőlt betú a proaktív szemléletet, az előremutató gondolkodást szimbolizálja, az ovális keret pedig a globális jelenlétet. ${ }^{31} \mathrm{~A}$ tény, hogy a cég négy könyvtárat felépített, bizonyítja, hogy követi az értékteremtő hagyományokat, ezzel egy időben kirajzolódik a négy dinamikus szervezet képességének markáns jelenléte, amelyek segítségével - reagálva a gyors környezeti változásokra - integrálja, kiépíti és újrakonfigurálja a külső és belső kompetenciákat. ${ }^{32}$ Ez a négy képesség az érzééelési, a tanulási, az integrálási, valamint a koordinációs képesség. ${ }^{33} \mathrm{Az}$ érzékelési képesség tette lehetôvé, hogy felismerjék a kommersz filmek kultúraközvetítő szerepét és a művelt, kiterjedt felvevőpiac intellektuális, inspirációs, valamint közösségés értékteremtő igényét, amelynek kielégítésére fenntartható keretet a könyvtár bizto- 


\section{JUHÁsz ÉVA}

síthat. A tanulási képesség az új intézményi szolgáltatás kialakításában nyilvánul meg, az integrációs képesség pedig abban, hogy ez a szolgáltatás a CRM-politika részévé vált. A koordinációs képesség segítségével az új feladatokhoz rendelték a megfelelő munkaerőt. A Hyundai könyvtár felhasználói számára azért jelent a könyvtár értéket, mert biztosítja az innovatív gondolkodáshoz és kreativitáshoz szükséges információs forrást, valamint a közösségi élményt. A vállalat számára pedig azért, mert ez az innovatív CRM olyan befektetés, amelynek során a meglévő és potenciális ügyfél számára már a banki szolgáltatás igénybevétele előtt is érték keletkezik. Fenntartható, hiszen a létrehozott közösség a továbbiakban már önállóan szerveződik, múködik, amelyhez a könyvtárban tartott programok és rendezvények is hozzájárulnak. E tevékenységek hosszú távra biztosítják az ügyfelek bizalmát, ezáltal fogyasztói hajlandóságát.

\section{A Hyundai Card gyakorlatának hazai adaptálhatósága}

Bár CRM tapasztalatról nem beszélhetünk, hiszen a Hyundai Card CRM stratégiájának kimenetele még ismeretlen, és a dél-koreai és hazai cégek külső környezete is eltér, a Hyundai szemléletmód elemei véleményem szerint adaptálhatóak: a Magyar Cirkusz és Varieté (MACIVA) majdani információs központja az alapítók szándéka szerint a közép-európai cirkuszmúvészet kutatását szándékozik felvállalni, illetve a nagyközönség számára fenntartható közösséget létrehozni. Ha ez az elképzelés a MACIVA CRM stratégiájának is részévé válik, akkor ez a jegyeladásokat kedvezően befolyásolhatja, így a könyvtár létrehozása nem csak költségként, hanem értékteremtő és fenntartható befektetésként is megjelenhet.

\section{Összegzés}

Miért válhatott tehát a könyvtár a Hyundai Card CRM eszközévé a Koreai Köztársaságban? A rendelkezésre álló információs források, valamint a személyes megfigyelés alapján ez több okra vezethető vissza. Az ország értékteremtő hagyománya, a kommersz filmek kultúraközvetítő szerepe, valamint a vállalat dinamikus szervezeti képességei egyaránt szerepet játszottak abban, hogy a banki szolgáltató felismerje: a könyvtár az ügyfélbizalom megteremtésének, végső soron a nyereségesebb szolgáltatásnak hatékony fóruma. A megközelítés szokatlannak tűnhet a közgazdászok számára, de a társadalomtudományi tanulmányokban rejlő válaszok bizonyítják, hogy mennyire fontos egy-egy kérdéskör interdiszciplináris vizsgálata. Más szóval: „Kérdez̨d a könyvtárost (is)!”

\section{Jegyzetek és irodalom}

1. RUST, Ronald T. - MOORMAN, Christine - BHALLA, Gaurav: Rethinking marketing. = Harvard Business Review, 88. vol. 1-2. no. 2010. 100-101. p. Forrás: http://web.a.ebscohost. com/ehost/pdfviewer/pdfviewer?sid=d1542162-0973-4785-8526-4636dcb4b3db\%40sess ionmgr4004\&vid=0\&hid=4112 [2018. június 25.] 
AKIKET A HITELKÁRTYA ÉS A KÖNYVTÁR ÖSSZEKÖT: A KÖNYVTÁR MINT A CRM...

2. MESTER Csaba: Hogyan válik a CRM a vállalatok versenyképességének meghatározó elemévé? = Vezetéstudomány, 37. évf. 1. sz. Klnsz. 2006. 90. p.

3. CHALCRAFT, Emilie: Design library opens in Seoul. = Dezeen, 15th March 2013. Forrás: https://www.dezeen.com/2013/03/05/hyundai-card-design-library-opens-in-seoul [2018. június 25.]

4. CHOI, Kyong-ae: Hyundai Card opens Travel Library = The Korean Times, 13th May 2014. Forrás: http://www.koreatimes.co.kr/www/news/biz/2014/05/488_157098.html [2016. szeptember 23.]

5. WU, Daven: Whisktaker : the Hyundai Card Cooking Library opens in Seoul. In: Wallpaper. (27th April 2017.) Forrás: http://www.wallpaper.com/lifestyle/hyundai-card-cookinglibrary-opens-in-seoul [2017. április 29.]

6. WU, Daven: Whisk take. The Hyundai Card Cooking Library opens in Seoul. = Wallpaper, 27th April 2017. Forrás: http://www.wallpaper.com/lifestyle/hyundai-card-cookinglibrary-opens-in-seoul [2017. április 29.]

7. Kyujanggak Library. Forrás: http://kyujanggak.snu.ac.kr/LANG/en/introduction/4_history. jsp [2017. november 17.]

8. Joseon Wangjo Sillok (Annals of the Joseon Dynasty). Forrás: http://kyujanggak.snu.ac.kr/ LANG/en/search/2_01_search_sillok.jsp [2017. november 17.]

9. Uigwe. Forrás: http://kyujanggak.snu.ac.kr/LANG/en/search/2_06_search_uigwe.jsp [2017. november 17.]

10. Choson Wangjo Sillok. Forrás: http://library.princeton.edu/resource/4673 [2017. november 17.]

11. BAE, Kichan - JEON, Sang-woon - KIM, Ho - PAK, Song-rae: King Sejong the great. The everlasting light of Korea, Seoul. Diamond Sutra Recitation Group, 2010. 7. p.

12. Uo. 84. p.

13. Uo. 87-88. p.

14. Uo. 94. p.

15. UNESCO International Literacy Prizes. Forrás: http://en.unesco.org/themes/literacy/ prizes [2016. január 16.]

16. BAE Kichan - JEON Sang-woon - KIM, Ho - PAK, Song-rae: King Sejong the great. The everlasting light of Korea, Seoul : Diamond Sutra Recitation Group, 2010. 8. p.

17. NAM, Moon-hyon: Jang Yeong-sil. Inventor of the striking clepsysra during the Reign of King Sejong in Joseon. Explorations in the history of machines and mechanisms. Proceedings of HMM2012. (Eds.) Koetsier, Teun, Ceccrarelli, Marco. Dordrecht, Springer, 2012. 83-106. p.

18. HILTY, Anne: Jeju's female icon of the Joseon era. How the businesswoman, philanthropist and role model Kim Man Deok saved the island's people. = The Jeju Weekly, 2011. 06. 24. Forrás: http://www.jejuweekly.com/news/articleView.html?idxno=1691 [2017. május 9.]

19. Ministry of Culture, Sport and Tourism. Forrás: http://www.mcst.go.kr/english/index.jsp [2016. november 7.]

20. National Library of Korea. Forrás: http://www.nl.go.kr/english/c1/page1.jsp [2016. október 20.]

21. KIM Kjongthe: A kommersz filmek fejlődése. Koreai típusú kasszasikerek. In: 9. Koreai Filmfesztivál : 2016. november 8-12. Budapest, Koreai Kulturális Központ, 2016. 14. p. 


\section{JUHÁSZ ÉVA}

22. PARC Jimmyn - HWY-CHANG Moon: Korean dramas and films. Key Factors for their international competitiveness. = Asian Journal of Social Science, 41. vol. 10. no. 2013. 128. p. Forrás: doi:10.1163/15685314-12341295 [2017. november 17.]

23. Tree with deep roots. Forrás: https://ondramanice.io/drama/tree-with-deep-roots-detail [2017. december 12.]

24. Great King Sejong. Forrás: https://ondramanice.io/drama/great-king-sejong-detail [2017. december 12.]

25. Sungkyunkwan Scandal. Forrás: https://ondramanice.io/drama/sungkyunkwan-scandaldetail [2017. december 12.]

26. Queen In-Hyuns Man. Forrás: https://ondramanice.io/drama/queen-in-hyuns-man-detail [2017. december 12.]

27. HYUN-KEY KIM, Hogarth: The Korean wave. An Asian reaction to western-dominated globalization. $=$ Perspectives On Global Development and Technology, 12. vol. 1-2. no. 2013. 139. p. Forrás: doi:10.1163/15691497-12341247 [2017. november 17.]

28. Heartbreak Library. Forrás: https://ondramanice.io/drama/heartbreak-library-detail [2017. december 12.]

29. Man to man. Forrás: https://ondramanice.io/man-to-man/watch-man-to-man-episode-1online [2017. december 12.]

30. PARC Jimmyn - HWY-CHANG Moon: Korean dramas and films. Key factors for their international competitiveness. = Asian Journal of Social Science, 41. vol. 10. no. 2013. 146. p. Forrás: doi:10.1163/15685314-12341295 [2017. november 17.]

31. WIDMAR, Aaron: Behind the badge. The secret meaning of the Hyundai logo. $=$ The NewsWheel (Added on February 6, 2015) Forrás: http://thenewswheel.com/behindbadge-secret-meaning-of-the-hyundai-logo [2017. november 21.]

32. TEECE, David J. - PISANO, Gary - SUHEN, Amy: Dynamic capabilities and strategic management. $=$ Strategic Management Journal, 18. vol. 7. no. 1997. 509-533. p. Forrás: http://links.jstor.org/sici?sici=0143-2095\%28199708\%2918\%3A7\%3C509\%3ADCASM \%3E2.0.CO\%3B2-\%23 [2015. július 8.]

33. PAVLOU, Paul. A. - EL SAWY, Omar. A.: Understanding the elusive black box of dynamic capabilities. Decision Sciences, 42. vol. 1. no. 2011. 239-273. p. Forrás: http:/ / eds.b.ebscohost. $\mathrm{com} /$ eds $/$ pdfviewer/pdfviewer?vid=10\&sid=e 510acae-2d4f-4374-b8cc-7ce1c7b37ff5\% 4 0sessionmgr120\&hid=112 [2015. szeptember 7.] Forrás: https://doi.org/10.1111/j.15405915.2010.00287.x

Juhász Éva a Magyar Képzőművészeti Egyetem Könyvtár Levéltár és Mưvészeti Gyújtemény könyvtárosa, az ELTE Irodalomtudományi Doktori Iskola Könyvtártudományi Doktori Programjának hallgatója. Jelenleg disszertációján dolgozik. Kutatási területe a modern menedzsmenteljárások adaptálhatósága könyvtári szervezetekben. 